\title{
Æstetikkens ramme
}

Derrida, Kant og det parergonale

\section{I. Æsstetikkens plads}

Et af de steder i Derridas værk, hvor han eksplicit nærmer sig spørgsmålet om det æstetiskes plads i filosofien, er i den fragmentariske analyse af Kants Kritik af dømmekraften, som findes under overskriften "Parergon" og udgør det første hovedafsnit i La vérite en peinture (1978). ${ }^{I}$ Ganske vist løber "æstetiske” problemstillinger gennem alle Derridas tekster, lige som kommentarer til litteratur og billedkunst ofte findes indflettet $\mathrm{i}$ hans læsninger af klassiske og moderne filosoffer, men altid på en måde som effektivt synes at stikke ud i forhold til mere gængse akademiske emneog genregrænser. Intet forekommer mere fremmed for Derrida end at udvikle en systematisk "æstetik" i form af en teori, som skulle tildele eksempelvis smagsdommen, kunstværket, den æstetiske værdi eller nogle andre af en sådan teoris mulige "objekter" en defineret plads ved siden af de metafysiske, erkendelsesteoretiske, etiske, politiske osv. områder. Snarere ville det være korrekt at sige, at dekonstruktionen begynder med at gøre alle sådanne demarkationslinjer usikre, og at et af dens formål er at undersøge de teknikker, med hvilke forskellige filosofier, først og fremmest fra Kants transcendentale vending og frem, har forsøgt at skelne forskellige sfærer af legitimitet og fornuftsanvendelse fra hinanden. Som vi skal se, bliver den juridiske distinktion, som vejleder Kant - forskellen mellem quid facti (hvad er fakta i sagen, hvordan ser vores domme og erfaringer faktisk ud) og quid juris (med hvilken ret kan de gøre krav på deres respektive pladser) - hos Derrida til en irreducibel sammenfletning, hvor Kants eksempel virker tilbage på hans regler, og det empiriske invaderer det transcendentale, men uden at vi af den grund helt enkelt skulle opløse det aprioriske element i en empirisk-sociologisk analyse, hvilket ville være lige så illusorisk som at forblive i det strengt transcendentale. I Kants forsøg på at ramme den æstetiske dom ind, som signifikant nok sker ved hjælp af instrumenter, som lånes fra den teoretiske dom og derfor giver anledning til en hel serie forskydninger og nødløsninger, udskiller Derrida et arbejde med rammen i alle dens betydninger. Importen af en logisk struktur, som både er og ikke er fremmed for det æstetiske og 
samtidig skal sikre dens forbindelse til fornuften, leder til en proces af indramning og aframning, kontraktion og ekspansion, som krydser ind i hinanden og skaber en zone af uafgørlighed. Det er i denne zone, Derrida lokaliserer idéen om rammen som et "parergon", et værk-ved-siden-af som alligevel er væsentligt for værkets "værkvirkende", for energeia hos ergon, men som ikke kan lokaliseres i det ydre eller indre, kun i deres fælles grænse, og udgør deres gensidige "invaginering".

I én forstand ville Derridas dekonstruktive læsning af Kants æstetik direkte kunne relateres til samtidskunstens undersøgelser af rammen og institutionens problemer fra tressernes konceptkunst og frem, hvor det ofte har handlet om at anvende sådanne grænser som produktive strategier. ${ }^{2}$ På hvilke betingelser fremstår et kunstværk som et værk? Hvordan forholder det tekstuelle og det visuelle sig til hinanden i en situation, hvor værket udelukkende kan bestå af en instruktion, en beskrivelse eller til og med sin egen titel? I hvilken grad kan indramningen varieres af eller til og med overlades til betragterens egen aktivitet? Fordrer oplevelsen af værket, at det ses som resultat af en ophavsmands intentioner, eller kan vi tænke os et generaliseret inskriptionsfelt, hvor kunstneren kun udgør en måske ligefrem uvæsentlig pol, eller er sådanne forsøg på at eksternalisere den skabende subjektivitet blot en måde at placere kontrollen på et højere niveau?

Derridas mistænksomhed over for forsøget på at indkredse eller indramme det æstetiske som en del af den filosofiske encyklopædi har naturligvis mange forlæg, og i den filosofiske tradition, som han eksplicit forholder sig til, kan rødderne til denne indstilling genfindes i den anden generation af fænomenologiske filosoffer fra Heidegger og frem. Inden for fænomenologien fører spørgsmålet om det æstetiskes plads hovedsageligt til to svar (og hermed rekapitulerer den også en konflikt i den tyske idealisme, fra Kant via Schelling og frem til Hegel), hvor det første fokuserer på det æstetiske som et objekt for studium, hvis a prioriske eller eidetiske forudsætninger kan formuleres i en generel teori, og det andet fokuserer på værkets "hændelse", hvor det gælder om at lade det opnå sin egen begrebslighed på en måde, som også vejleder og forvandler filosofien selv. Hos Husserl forekommer refleksioner over æstetiske problemer yderst sporadisk, og selv om han på forskellige tidspunkter aner en parallel mellem fænomenologiens epoche og den æstetiske betragtning, ${ }^{3}$ synes denne nærhed aldrig at være blevet til et afgørende problem for ham, og den kom aldrig for alvor til at sætte spørgsmålstegn ved den teoretiske indstillings prioritet. Flere af hans efterfølgere forsøgte imidlertid snart at fylde dét, de opfattede som et tomrum i fænomenologien, og i 1928 kunne Werner Ziegenfuss publicere en afhandling med titlen Die phänomenologische Ästhetik, som ser tilbage på et decenniums teoretiske udvikling i kølvandet på Husserl, hvor spørgsmålet om det æstetiskes egenart stod i centrum, dvs. det som i Husserls vokabular kunne kaldes kunstværkets "regionale ontologi" ${ }^{4}$ Roman Ingardens unders $\emptyset$ gelse af det litterære værks betydningslag udgør et af knudepunkterne i denne udvikling, som fortsættes efter krigen i eksempelvis Mikel Dufrennes systematiske analyse af den æstetiske erfarings fænomenologi. ${ }^{5}$

Men i modsætning til disse unders $ø$ gelser af det æstetiskes specificitet - som indtager en given plads i den tidlige modernismes søgen efter en ren synlighed, et rent ord, en ren musikalsk form osv., og i dette aspekt er del af en formalistisk kunstteori 
- må man imidlertid udskille en anden linje, som tager sin begyndelse hos Heidegger og fortsættes på anden vis i Merleau-Pontys undersøgelser af forholdet mellem fænomenologien og det modernistiske maleri som to former for oprindelig sanselighed (mens derimod Sartres analyser af det imaginære og litteraturens status må siges at tilhøre den første linje) og i Gadamers hermeneutik, hvis generelle model for forståelse synes at leveres af kunstværket. Hvad gælder det æstetiskes plads - eller snarere ikke-plads, dets flakkende pladsløshed - er det uden tvivl i et komplekst forhold til begge disse traditioner, Derrida kan lokaliseres, i den forstand at dekonstruktionens strategi består i til stadighed at bebo deres marginaler og hente energi fra deres modsigelser. Det ville derfor være forhastet, at - som det nogle gange sker - direkte indrangere Derrida i den tradition, som i det æstetiske, eller snarere i en idé om en kunst som ville være skjult inden i det æstetiske, ser et utopisk løfte om en forvandling af filosofien. ${ }^{6}$ Dekonstruktionen er på den ene side en måde at genindskrive sådanne løfter i det rum, de tror sig at overskride, og tanken om et radikalt Ydre er for Derrida den illusion, som driver metafysikken fremad: fantasien om en slutgyldig overvindelse af metafysikken er det egentligt metafysiske; på den anden side kan den filosofiske diskurs' interioritet kun oprettes gennem operationer, som har lige så meget at gøre med litterære og retoriske teknikker og ikke bare er en ydre klædning for tanken. På sådan vis må den bevægelige linje, som hos Derrida forbinder og adskiller filosofi og litteratur, permanent trækkes på ny, og den generelle "skrift", som alle disse diskursive former bebor, er intet overordnet begreb, i hvilket deres specifikke forskelle ville kunne opløses.7 Allerede fra begyndelsen er vi i "Platons apotek", hvor den filosofiske fremstillings forskellige dele befinder sig i en plasmatisk tilstand og ikke kan beskrives gennem de distinktioner, som en vis "platonisme" derefter har muliggjort. ${ }^{8}$

Den grundlæggende afvisning af begrebet "æstetik", hvortil alle efterfølgerne refererer, findes hos Heidegger, hvor linjerne fra den tyske romantik løber sammen på ny og brydes som $i$ et prisme for siden at løbe videre i den moderne tænkning. For Heidegger udgør det moderne æstetikbegreb helt enkelt en konsolidering af metafysikkens indledende forskel mellem det sanselige og det intelligible, to aistheton og to noeton, og en overvindelse af den græske ontologi må også gælde æstetikken. I denne forstand er kunstens underkastelse under den æstetiske betragtelsesmåde indskrevet i filosofien fra dens faktisk begyndelse (Beginn) nogetsteds i det antikke Grækenland, selv om den først virkeliggøres på et terminologisk plan langt senere. Men for at denne historiske arkæologi, som frisætter det "utænkte" (das Ungedachte) i æstetikken, skal have en positiv betydning, må kunsten som sådan også indeholde en dimension, som altid allerede har undsluppet det æstetiske, som udgør en skjult ressource og dermed forbereder anden eller en anden begyndelse (andere Anfang), mod hvilken den tilbageskuende læsning bevæger sig som mod en endnu ubestemt fremtid. "Den vesterlandske refleksion over kunsten begynder (beginnt) som æstetik", skriver Heidegger i forelæsningsrækken om Nietzsche fra 1936, "Der Wille zur Macht als Kunst", men alligevel er det tilfældet, at "den store græske kunst forblev uden en modsvarende tænkning og begrebslige overvejelser, hvilket ikke behøvede at være ensbetydende med æstetik". ${ }^{9}$ Denne historiske model styrer også den mere strukturelt indrettede fremstilling i Kunstværkets oprindelse, hvis afgørende 
spørgsmål optræder i temaet for et af de foredrag, der tjente som udgangspunkt for den senere publicerede tekst, "Die Überwindung der Ästhetik in der Frage nach der Kunst”. Man må altså understrege, at en sådan overvindelse af æstetikken ikke skal forstås som noget negativt lige så lidt som den "destruktion af ontologiens historie", som skitseredes i Væren og Tid (§ 6) skal det, men at den tværtimod sigter mod at frisætte os til en anden erfaring, en forvandlet relation til kunsten som en "afdækning" hinsides (eller på denne side af) æstetikken i alle dens klassiske og moderne former. For Heidegger når denne metafysiske indramning sin første fuldbyrdelse hos Hegel, hvor kunsten bliver til noget "overstået" i åndens udvikling, ${ }^{\text {10 }}$ for siden at slås i stykker hos Nietzsche - "den mest tøjlesløse platoniker i den vesterlandske metafysiks historie", ${ }^{\text {II }}$ som Heidegger siger i et af sine negative øjeblikke - og hvor fokuseringen på kunsten som "oplevelse" (Erlebnis), rus og affektivitet driver det æstetiske til dets yderste grænse. I efterordet til Kunstværkets oprindelse noterer Heidegger, at oplevelsen, den moderne, subjektiviserede og "æstetiserede" form af det græske aisthesis, er det element, i hvilket kunsten dør, omend denne proces kan tage flere hundrede år for at blive fuldbyrdet. Men, tillægger han i en håndskreven marginaloptegnelse, dette betyder ikke, at kunsten skulle være noget overstået, bare at vi må finde et "et helt andet 'element' for kunsttilblivelsen". ${ }^{2}$ '

Dette andet element handler for Heidegger om en sandhed, som ikke kan reduceres til en korrespondence (homoiouisis, adaequatio) mellem repræsentation og yderverden, men tværtimod består i den sandhedsskéen (aletheia), som åbner en verden som sådan og først derefter tillader forskellige former for repræsentationer og relationer mellem mennesker, genstande og udsagn at etableres. For Derrida forbliver dette en vision, som i sin søgen efter kunstværkets "oprindelse" er lige så problematisk som den mimetiske tradition, den vil efterlade bag sig - hvis der findes en "sandhed" i kunsten, som Heidegger hævder, eller en "sandhed i maleriet" med den vending fra Cézanne som har givet titel til bogen La vérité en peinture, ${ }^{\mathrm{I} 3}$ så er dette en sandhed, som kun kan gives indirekte i form af paradokser. Ganske vist er værkets sandhed for Heidegger altid betinget af den dybere "rids" (Riß), som åbnes mellem jord og verden, det lukkede og det åbne, og den fænomenologiske givethed grundes i en dybere forskel (den ontologiske differens), men for Derrida er dette stadig i al for høj grad indskrevet i en teleologisk orden, i al for høj grad afhængigt af en hermeneutisk model for tilegnelse, beherskelse og genoprettelse, hvilket eksempelvis fremgår af den lange diskussion af debatten mellem Meyer Schapiro og Heidegger, som afslutter La vérite en peinture (291-436), hvor det ikke så meget drejer sig om at give en af dem ret som at undersøge det begær efter at "tilbagegive" van Goghs sko til deres retmæssige ejer: Schapiro-manden fra byen eller Heidegger-manden fra landet (her finder vi også nogle af Derridas mest syrlige kommentarer om Heidegger, 334f.).

Hvad der forstås ved det, som den filosofiske tradition har forsøgt at indkredse med termen "æstetik", bliver for Derrida til en udfordring for det filosofiske begreb og dets greb, men ikke som noget blot og bart ydre, heller ikke som en sandhed som skulle vende tilbage til os for enden af en lang rejse (metafysikkens historie som historien om værens skjulthed [undandragande], som til sidst lader sig tænke netop som skjulthed, Lethe), men derimod som en indre uro, som får det æstetiskes ram- 
mer til at briste, men også til stadighed genskaber dem. På en måde, som i grunden synes at minde mere om Adornos negative dialektik end Heideggers vision af en oprindelig sandhed skjult bag æstetikkens vold, består udfordringen for Derrida i inden for og via begrebets (logiske, subsumerende, voldsomme) bevægelse at tænke ikke-begrebet og det ikke-identiske på en sådan måde, at det ikke-begrebslige aspekt af smagsdommen ikke bare fremstår som en irrationel dimension, det undslippende hos et nøgent "dette" som helt enkelt ville være uden begreb, men som et "uden-begreb" - et sans-concept som Derrida siger, dvs. noget som via den lydlighed med sang ("blod"), som Derrida ofte spiller på, også kan forstås som et sår, et snit som giver ophav til en tænkning, som på én gang er lyst, ulyst og bearbejdning - som bevarer ikke-identiteten i identiteten eller, i Kants termer, bevarer momentet af refleksion inden for bestemmelsen, men uden at stille dem over for hinanden som enkle modsætninger.

\section{Dommens indramning}

Hvis Kant i Kritik af dømmekraften lægger grundstenen til den moderne æstetik, så gør han det på en måde, som skaber en tydelig ambivalens, som siden er kommet til at kendetegne de fleste forsøg på at formulere en filosofisk forståelse af ikke bare enkelte kunstværker, men af betydningen af eksistensen af kunst og æstetisk erfaring i det hele taget, forstået i deres bredeste forstand som spørgsmål stillet til tænkningen. Spørgsmålet om, hvordan den tredje Kritik skal læses - som en del af en filosofisk arkitektonik, som en behandling af et specifikt problem eller som det punkt, hvor Kant drives til at forsøge at beskrive muligheden for sit eget system og derfor støder ind i selvrefleksive paradokser - er derfor ikke bare et filosofihistorisk, men i højeste grad også et samtidigt problem, og Derrida driver dette spørgsmål om læsningens mening, også på et rent tekstuelt plan, til dets yderste grænse.

De to første Kritikker havde indkredset to autonome områder, erkendelsen og etikken, den teoretiske og den praktiske fornuft, og kritikkens opgave er at skelne mellem disse to lovgivninger for at undvige det "dialektiske skin", som optræder, når de gør indgreb på hinandens områder. Mellem disse to naturer, den sanselige og den oversanselige, findes en "uoverskridelig kløft", ${ }^{\mathrm{I4}}$ siger Kant - men dermed stilles også spørgsmålet om, hvorvidt der gives en mulig forsoning mellem natur og frihed, mellem det sanselige og det oversanselige. En "bro", hævder Kant, må kunne slås fra den ene side til den anden, og denne bro kommer til at blive smagsdommen, som relaterer til den subjektive følelse af lyst og ulyst, og hvor muligheden for at forbinde erkendelsens sanselighed og moralens oversanselighed etableres. I den æstetiske dom findes således en anelse om helhed og en mulig forsoning. For Derrida er en sådan idé om grund og enhed en variant af den metafysiske idé om et centrum, som på en og samme gang produceres og holdes på afstand inden for filosofien som et begær, og som alt begær lever af sin egen umulighed. Begæret efter grunden leder os derfor ned i en afgrund, et fravær af grund, men uden derigennem at styrte os ned i det rent bundløse: "Analogien om afgrunden og broen over afgrunden er en analogi for at sige, at der må kunne være en analogi mellem to absolut heterogene verdener, en tredje 
for at kunne passere afgrunden, at kunne læge det åbne sår til et ar og tænke adskiltheden" $(P, 43)$.

Analytikken af den æstetiske dømmekraft har hos Kant en dobbelt funktion: for det første at etablere det æstetiskes autonomi, dets legitimitet som et område uafhængigt af erkendelsen og etikken; for det andet at vise, at netop denne autonome æstetik muliggør en slåen bro over kløften eller kan ligge til grund for en ny slags harmoni mellem det sanselige og det oversanselige. Det er dette, som giver ophav til ambivalensen i Kants argumentation, som siden skulle komme til at give genlyd i romantikken og en stor del af den moderne filosofi: er den æstetiske erfaring en egen sfære med egne principper a priori, som skulle gøre den selvstændig over for forstandens og fornuftens respektive lovgivninger om erkendelsesevnen og begærsevnen, eller er den i al væsentlighed underordnet det kognitive og/eller det normative? Kants efterfølgere i den romantiske generation forsøger alle at overskride den æstetikkens grænse, som den kritiske filosofi har etableret, idet de projicerer kunstværket som en absolut enhed eller en "intellektuel anskuelse", og metoden til at opnå dette er at rejse den æstetiske autonomi, så den bliver til en æstetisk suverænitet, en evne til at skabe grundvolden for en ny verden. ${ }^{15}$ Dette er ganske vist noget, som Kant selv ville have vægret sig mod, og hans kampskrift mod samtidens "mystagoger" og "sværmere" og den "fornemme tone", de har stemt filosofien med, er en tydelig indikation på dette. ${ }^{16}$ Men ikke desto mindre er den romantiske ekspansion af begrebet kunst - som formodentlig første gang dukker op hos Schelling som et singulare tantum, hvor "die Kunst" fremtræder som en kategori overordnet de enkelte kunstarter ${ }^{17}$ - en konsekvens af det filosofiske problem, som Kant (måske mod sin vilje) etablerer, nemlig hvordan kunsten og den æstetiske erfaring kan bidrage til en sandhed, som handler om fornuftens relation til sig selv.

I det skønnes analytik indkredser Kant smagsdommens egenart i fire momenter: kvalitet, kvantitet, relation og modalitet, og i "Parergon" følger Derrida Kants argument skridt for skridt, eller snarere på en måde som i dybden problematiserer, hvad et skridt (pas) er, og undertiden fører os over i spørgsmålet om, hvorvidt skridtet ikke i lige så høj grad skal forstås som et "ikke" (pas) - en dobbelttydighed som Derrida udnytter til det yderste, men som også siger noget væsentligt om den egenartede rytme i Kants fremstilling, hvilket bliver tydeligst i paragrafferne om det sublime. Her skal jeg begrænse mig til at kommentere visse af de afsnit i Derridas tekst, som gælder det skønne, men dette kan alligevel give et relativt tydeligt billede af, hvordan han nærmer sig Kants problemer (og det er også her, den "parergonale" logik står i centrum).

Det første moment, kvalitet, indebærer, at det velbehag, jeg føler over for genstanden, skal være interesseløst. Dette skal ikke forstås som uinteresse eller ligegyldighed (sådan misforstår eksempelvis Nietzsche Kants argument, og det er værd at notere, at dette er en af de få henseender, hvor Heidegger forsvarer Kant) ${ }^{18}$ for hvis jeg ikke bedømmer genstanden direkte moralsk eller praktisk, så er det, fordi jeg på en vis måde lader den være sig selv. Min interesseløse relation til genstanden er ikke praktisk, men kontemplativ, hvilket betyder, at jeg er opmærksom på, hvad den gør med mig, med min sensibilitet, snarere end på hvad jeg vil gøre ved den. Smagsdommen er en reduktion af begæret, det sætter begæret ud af spil for et øjeblik, men 
med det formål at frisætte en anden sensibilitet, en anden lyst end den som er rettet mod den praktiske formålstjenlighed.

Allerede på de første linjer i teksten skabes der imidlertid en mærkværdig relation mellem denne frie lystfyldte dom og forstanden, som kommer til at vejlede Derrida: vi bindes af en tynd tråd til erkendelsen og fornuften, og samtidig, som Kant foreslår i en ejendommelig reservation, er indbildningskraften "muligvis" (vielleicht, § 1) forbundet med forstanden - som var det et spørgsmål om en empirisk hypotese, hvis funktion i en transcendental kritik ikke kan være andet end paradoksal. Og desuden, i en note længst nede på første side lagt til overskriften, som altså logisk set foregår i tekstens $\S 1$ selv om vi sandsynligvis læser den efterfølgende, ${ }^{19}$ præciserer Kant, at det er dømmekraftens logiske funktioner som har tjent til at "vejlede" og styre analysen af det skønne, for heri findes "altid" (immer noch) en relation til forstanden. Som Derrida noterer, våger logikken i form af Kritik af den rene fornuft ved horisonten og styrer fra en vis afstand, diskret men dog på afgørende vis, hele fremstillingen af de æstetiske domme. Vi fastholdes inden for erkendelsens sfære via et logisk rammeværk, samtidig med at æstetikken uafladeligt kommer til at bearbejde, opløse og gøre modstand mod denne indrammende vold. Hele Derridas læsning i "Parergon" får til formål at vise, hvordan disse rammer forbliver åbne og klaprende, men uden nogensinde helt at forsvinde - hvilket også genspejles i tekstens legelystne typografiske form, hvor de forskellige mere eller mindre fragmenterede tekstafsnit rammes ind af rammer, som ikke lukkes.

Denne neutralisering af objektet er også en reduktion af subjektet i dets naturlige affektive betydning, og den fører os til en mellemliggende zone eller "midte" (den svævende Mitte, som er indbildningskraften, og som har tiltrukket læsere af Kant fra Fichte til Heidegger), ${ }^{20}$ et før-subjektivt subjekt og et før-objektivt objekt, hvor vi kan se den æstetiske bros karakter af hverken-eller: den berører begge sider, slås fra den ene side til den anden, men har dog en relativ autonomi i selve sin passage. Skal vi forstå denne passage med udgangspunkt i dens resultat (en af de to sider, rejsens destination) eller i processen omkring at slå bro? Derridas læsning, som her rekapitulerer og genindskriver hele den debat, som blev indledt af Kants umiddelbare efterfølgere (selv om Hegel er den eneste, som eksplicit nævnes), kommer til at dreje sig om problemet om, hvordan denne mellemliggende sfære, denne "mellemliggende del" eller "mellemled" (Mittelglied), som er indbildningskraften, kan være en integreret del af systemet, samtidig med at den nogle gange, til visse formål, kan forstås som aftagelig og selvstændig.

En sådan sfære, hvor subjekt og objekt er blevet reduceret - som Derrida i mange formuleringer lader grænse op til den fænomenologiske epoche hos Husserl - ville være en ren situation, hvor vi på rigorøs vis kunne afgrænse det indre fra det ydre i oplevelsen, det interne fra det eksterne, og således fælde en ren smagsdom. Men for at denne sfære skal kunne frisættes, må en anden betingelse imidlertid foreligge, og den kan hverken forstås som rent ydre eller indre, men er beliggende ved grænsen mellem dem: en ramme må føres ind - men hvorfra, hvordan, med hvilken ret? Æstetikkens autonomi beror på, hvordan dette spørgsmål besvares, og som Derrida viser, kommer Kant - med afsæt i den første tvetydighed omkring de logiske dommes styrende funktion i relation til de æstetiske - til at introducere den på en måde, 
som til stadighed sammenblander det faktiske og det principielle, a posteriori og a priori, quid facti og quid juris. Hans rammer krakelerer og føjes sammen på ny, repareres med forskelligt materiale, som lånes fra de andre Kritikker, dvs. fra erkendelsen og etikken, hvilket viser, at rammen aldrig er noget færdigt, men tværtimod en proces af ind- og aframning, som producerer effekter af transcendentalitet, som aldrig kan tages for givne, men heller ikke helt viskes ud.

I det andet moment, kvantiteten, vil Kant vise, at velbehaget ikke er baseret på begreber. Smagsdommen hverken producerer eller hviler på en specifik erkendelse, som skulle tillade os at formulere en regel, som angiver, hvorfor noget er skønt. Det skønne er dermed altid noget personligt, det er ikke visse typer af værker eller en vis kunstners produktion, som kan tilskrives skønhed i almenhed, men altid dette som er foran mig, lige nu, lige her. Men samtidig er det ikke genstandenes objektive egenskaber (farve, form, komposition osv.), som bedømmes i sig selv, men den følelse af velbehag og harmoni, de giver ophav til, når de reflekteres i subjektets indre sensibilitet. Jeg bestemmer ikke genstanden, som om skønhedsdommen var en erkendelsesdom, men jeg reflekterer over den og holder, så at sige, min dom svævende mellem subjektivitet og objektivitet, og i denne svæven opnås en begrebsløs lyst. Men som Derrida påpeger, er denne lyst imidlertid ikke modsat eller helt enkelt uden, uden for begrebet, men netop et kompleks, som han kalder uden-begreb, sans-concept. I denne struktur af løsrivelsens "uden" (som forgrener sig i de tre første momenter: uden interesse, uden begreb, formålstjenlighed uden formål), i dets sans, findes, som vi har set, også et sår, et blødende snit eller "det rene snits uden/ blod" (le sans de la coupure pure), hvilket Derrida længere fremme, i analysen af den formålsløse formålstjenlighed, også beskriver i termer af et "ikke-vidende" $(P, 102)$, som ikke bare er en tomhed, men et "spor af uden" (P, 103), som frisætter lysten. Uden interesse, lyst og bestemt formål er skønheden en flakken, som unddrager sig såvel det kognitive som det etiske, men dog "muligvis" (vielleicht), "altid" (immer noch), har en væsentlig relation til dem og indrammes af dem.

Men lad os vende tilbage til lysten: af hvilken art er denne mærkværdige følelse, som træder frem i den dobbelte suspension af det subjektive og det objektive? Den er berøvet begrebet og berøvet den sanselige nydelse - med andre ord en lyst som er "en smule tør" $(P, 51)$, som ikke forholder sig til genstanden eller til mig selv som fysisk væsen, men blot eksisterer i en refleksion, som relaterer den til sig selv i en bevægelse af "selvaffektion" i den grad, den berøver sig selv begge poler, subjektet og objektet; det er en lyst, som kun opstår via en afholdenhed, epoche, fra alt, som hører til verden, inklusiv mig selv og det, som i mig hører under min begærsevne, men en lyst som samtidig også er en ren "heteroaffektion", dvs. muligheden for et ydre i det hele taget. En lyst som består i reduktionen, begrænsningen, indramningen af en ren situation, og som derfor giver ophav til en vis "sorg" $(P, 52)$ i forhold til skønheden og "placeringen $i$ en krypt af alt det, som eksisterer" (54), men hvis betydning stadig må forforstås, for at det skønnes Analytik skal kunne åbnes.

For Kant har denne lystens egenartede stilling at gøre med, at den på ingen måde er noget strengt privat, men stammer fra vores evne til at kommunikere, fra det som åbner mod et intersubjektivt fællesskab, thi dette, siger Kant i den vigtige $\S 9$, er "nøglen til smagskritikken". Dét, han kalder "bedømmelse" (Beurteilung), er 
stadig ikke en artikuleret dom (Urteil), men et første frit og ureguleret samspil mellem forstandens begreb og indbildningskraftens frihed, hvor deres respektive brug endnu ikke er blevet specificeret, men som derfor også, netop gennem denne endnu ubestemte åbenhed, på fundamental vis kobler den æstetiske oplevelse til friheden og et muligt fællesskab.

\section{Parergon}

Den tredje egenskab er, at genstanden bedømmes som formålsløs formålstjenlighed. Alt i genstandens form er orienteret mod et formål, som alligevel ikke er noget andet end genstanden selv; der findes ingen ekstern funktionalitet, genstanden er ikke til for andet end sin egen skyld. For Kant ligger dette til grund for forskellen mellem fri og vedføjet skønhed (pulchritudo vaga og pulchritudo adhaerens); kun den frie eller vage skønhed tilkommer kunsten, mens den vedføjede forudsætter et formål for formen, og i dette tilfælde er genstanden skøn, fordi den er tilpasset et formål som eksempelvis ved en brugsting. Det vage er her ikke at forstå som det dunkle eller utydelige (det er ikke en mangel på perfektion, hævder Kant over for Baumgarten), men indebærer, at tilbagetrækningen af formålet giver ophav til en autotelisk fuldendelse, som bevirker, at det, vi bedømmer som skønt, på den ene side er noget i sig selv lukket, samtidig med at det også, hvilket Derrida understreger, på den anden side er en "flakken" (errance), en spredning og såning af tegn og betydning (dissémination).

Det er egentlig først i dette tredje moment og mere præcist i § 14 med overskriften "Afklaring ved eksempler", at Derrida finder begrebet parergon, som han siden generaliserer til at gælde hele strukturen i Kants tekst i kraft af en ejendommelig genapplikation af Kants argument på teksten selv, som om den selv var genstand for en æstetisk dom. Kant vil i denne paragraf (som de fleste kommentatorer sædvanligvis har forbigået i tavshed eller anført som eksempel på det håbløst tidsbundne i argumentet) give eksempler på ren form, og det fører ham til nogle umiddelbart særprægede, men i grunden helt kohærente sidespring, som leder os mod grænserne for hele det skønnes analytik, mod dets randbetingelser. Det gælder forskellen mellem empiriske og rene eller egentlige smagsdomme, i hvilke intet empirisk velbehag, ingen retning eller bevægelse, må blande sig. Mange hævder, at materien er vigtig, noterer Kant, og den kan ganske vist tænkes som ren (vi kan forestille os rene farver og toner, hvilket han fors $\emptyset$ ger at bevise i en ekstremt presset argumentation); men i sidste instans er formen dog det eneste, som med vished lader sig kommunikere, mens fornemmelsens kvalitet (farven, tonen) kan variere mellem subjekterne. Renhed hører kun til formen, hvor man kan abstrahere fra fornemmelsens kvalitet.

At formen skulle kunne øges gennem pirringer er en skadelig fordom, fortsætter Kant - men alligevel kan de virke befordrende for smagen, særligt hvis den er ukultiveret, via et supplement som kompenserer for en mangel, som de jure ikke er der, ikke kan være der, kun de facto. Sådanne supplementer - parerga, siger Kant og giver eksempler som "et billedes ramme eller draperierne om en statue eller søjlegange rundt om prægtige bygninger" (§ 14) - må dog ikke tiltrække sig al for meget interesse som eksempelvis i tilfældet med "en guldramme omkring et maleri", som 
bare har til henblik "at anbefale det til vort samtykke" og "derfor forstyrrer det den ægte skønhed og omtales som et smykke" (Schmuck). Sådanne parerga bidrager kun i lille grad, de anerkendes udelukkende på det vilkår, at de ikke forstyrrer den skønne form, dvs. i form af en økonomisk kalkyle, hvor det gælder om at dosere pirringen (og her kan vi genkende den struktur som regulerer funktionen farmakon hos Platon). Et parergon er ikke en indre bestanddel, men et ydre tillæg, som øger smagens velbehag, men kun gør dette gennem sin egen form, præciserer Kant - en form som i sig selv er underordnet den skønne form, en slags sekundær form uden egen autonomi: rammer, draperier, søjlegange.

I denne parergonale logik ser vi, hvordan det indre og det ydre skifter plads i overensstemmelse med en supplementets logik. Maleriets ramme er en materiel version af den dommens ramme, som lånes fra erkendelsen for at "indramme" smagsdommen og i forlængelse heraf også den ramme, som omgiver værket og genererer den æstetiske autonomi på alle niveauer, fysisk, metaforisk, institutionelt osv. I egenskab af hverken indenfor eller udenfor er den et ydre, som invagineres i det indre for på én gang at konstituere dets interioritet og kompensere for dets mangel: det indre er ikke indre, hvis ikke det ydre invagineres og stødes ud i en ikke-lokaliserbar virkning "ved siden af" værket, par-ergon. Rammen er alt og intet, og altså ville det være illusorisk over for rammens vold at stille visionen om en ren aframning (décadrage); i stedet må vi unders $\varnothing$ ge rammen som strategi, effekt, hverken a priori eller a posteriori, men ved deres stadigt bevægelige grænse.

Til sidst, i det fjerde moment, gælder det for Kant om at vise, at smagsdommen har en vis nødvendighed. Når jeg fælder en smagsdom, udtaler jeg mig ikke om mine rent sanselige tilbøjeligheder, men gør krav på en særlig slags almengyldighed, dog godt nok ikke med lige så stærk nødvendighed som i erkendelsens tilfælde. Smagen er en svævende mellemting - hvilket er én af de ting, som metaforen "bro", som Kant foreslår i indledningen, indebærer - den er hverken rent subjektiv eller rent objektiv, men en intersubjektivitet i færd med at blive til. Deraf dimensionen af fællesskab i skønheden som et løfte om lykke: når jeg siger "dette er skønt", fordrer jeg, at alle andre skal samtykke, på trods af jeg ved, at dette faktisk ikke behøver være tilfældet. Jeg forsøger at finde det fælles for mig og andre, jeg "fælder dommen på enhvers vegne", siger Kant. Smagen hviler på en "fælles sans" (sensus communis), som vi kan antage som en indre natur, og som frem for alt kommer til udtryk i den lyst, som ligger i at kommunikere vores følelse og få andre til at samtykke.

Argumentet videreudvikles i "deduktionen" af smagsdommen, hvor Kant fors $\emptyset$ ger at vise, med hvilken ret vi i det hele taget fælder smagsdomme, som gør krav på enhvers samtykke, og hvor den forbindelse til forstanden, som blev antydet allerede i § 1, skal retfærdiggøres. I den frie refleksion over genstanden, siger han, optræder en stemning og proportion mellem forstanden og indbildningskraften, som også hører til erkendelsen $i$ det hele taget, selv om den i dette tilfælde ikke består i en speciel erkendelse, og derfor har vi i dommen ret til at gøre krav på gyldighed for enhver. Argumentet kan synes svagt; man kan spørge sig, hvorfor ikke alle ting, om hvilke vi kan få erkendelse, er lige skønne, givet at den proportionalitet, som skabes i smagsdommen, ikke er nogen anden end den, som findes i erkendelsen; eller omvendt, hvis denne proportionalitet er noget principielt andet, så har Kant ladt os i stikken, 
når det drejer sig om at forklare, hvad den rent faktisk er. ${ }^{21}$

Hvorvidt denne indvending kan afvises med argumenter hentet fra Kants egen tekst, behøver ikke at bekymre os her; snarere kan vi se problemet som et symptom. Undertiden knytter Kant smagsdommen så hårdt til erkendelsen, at dens originalitet synes at gå tabt: det skønne skulle bare være en foregribelse af erkendelsen i egenskab af en lyst, altimens den faktiske erkendelse kun kan erindre sig denne lyst som et svagt minde, som et spor af noget som "[faktisk forekom] på et tidspunkt" (ist gewiss zu ihrer Zeit gewesen), som Kant siger i en mærkelig passage i indledningen (afsnit VI) - en "arke-lyst", siger Derrida, som stadig findes skjult inden i erkendelsen, hvilket antyder, at kritikken også rummer en genealogisk dimension, i hvilken vi skulle kunne frilægge den historiske proces, hvorigennem den æstetiske autonomi og "det rene snits blod/uden" er kommet til at give ophav til et spor eller en ardannelse i fornuften selv. Til tider orienteres det skønne snarere mod moralen og den praktiske fornuft, f.eks. når Kant behandler skønheden som en "intellektuel interesse" (§ 42) eller som "symbol på det sædelige" (§ 59). Her er argumentet snarere, at den harmoni, vi føler mellem forstand og indbildningskraft, foregriber en verden, som ville være tilpasset mine moralske formål, et argument som først får sin fulde betydning i bogens anden del, Kritik af den teleologiske dømmekraft. ${ }^{22}$

Disse skiftende indfaldsvinkler behøver ikke ses som tegn på en inkonsekvens hos Kant, men på at æstetikken og det skønne er et flerdimensionelt fænomen, som ikke på nogen enkel eller stilfuld måde lader sig indføjes i den rene fornufts bibliotek (filosofien opdager et nyt område, som den kan klassificere ved siden af andre), men fordrer en voldsom omorganisering af fornuftens system, idet det på samme tid udlover en ny systemisk enhed og fremtvinger et nyt organisationsprincip, om end dette bare forbliver en anelse hos Kant, som han desuden flere steder skyder fra sig. Derridas "Parergon" frisætter de lag i Kants tekst, hvor denne dobbelte operation sker, og viser, hvordan de indrammende og voldsomme operationer, som den kritiske filosofi underkaster det æstetiske, altid efterlader et hul, en åbning, hvor dekonstruktionen kan tage sin begyndelse - ikke med det formål at ødelægge Kants tekst, ikke med det formål til sidst at lade den bag sig til fordel for en anden teori, men for at gøre os opmærksomme på rammens arbejde.

\section{Oversat fra svensk af Peter Bo Andersen}

\section{Noter}

I Se "Parergon" i La Vérité en peinture (Paris: Flammarion, 1978); Herefter citeret løbende i teksten $\operatorname{som} P$, med sidetal.

2 For en diskussion af dette, se forordet i Sven-Olov Wallenstein (red): Konceptkunst (Stockholm: Raster, 2006). Derridas forhold til de visuelle kunstarter behandles i Peter Brunette og David Wills (red): Deconstruction and the Visual Arts: Art, Media, Architecture (Cambridge: Cambridge University Press, 1994), hvor Kant berøres i flere af bidragene, selv om forholdet til den konceptuelle kunst, som synes mest produktivt, mærkeligt nok kun berøres i forbifarten.

3 Se brevet til Hugo von Hofmannsthal fra 12. januar 1907, Husserliana Dokumente, Briefwechsel (Dordrecht: Kluwer, 1994) vol. VII, 133-136. Jeg diskuterer dette brev og forholdet mellem "ren" 
kunst og "ren" fænomenologi i kommentaren til den engelske oversættelse i Site 26-27, 2009.

4 Werner Ziegenfuss, Die phänomenologische Ästhetik (Berlin: Arthur Collignon, 1928). Den fænomenologiske æstetiks tidlige historie er endnu relativt uudforsket; for to oversigtsværker, se Gabriele Scaramuzza, Le origini dell' estetica fenomenologica (Padua: Antenore, 1976), og Georg Bensch, Vom Kunstwerk zum ästhetischen Objekt. Zur Geschichte der phänomenologischen Ästhetik (München: Fink, 1994).

5 Roman Ingarden, Das Literarische Kunstwerk (Halle: Niemeyer, 1931); Mikel Dufrenne, Phénoménologie de l'expérience esthétique (Paris: PUF, 1953).

6 Se for eksempel Habermas, Der philosophische Diskurs der Moderne (Frankfurt am Main: Suhrkamp, 1985), kap. 7, og mere subtilt, men i bund og grund lige så misforstået, Jay Bernstein, The Fate of Art: Aesthetic Alienation from Kant to Derrida and Adorno (Cambridge: Polity Press, 1992), kap. 3.

7 I Derridas mangefacetterede studier af forfattere som Celan, Artaud, Joyce, Ponge, Mallarmé og Cixous (for bare at nævne nogle vigtige eksempler) handler det om at konfrontere deres tekster med filosofiske standpunkter på en måde, som ganske vist sætter "genrens lag" på spil, men ingenlunde udgør nogen "udviskning af genregrænsen mellem filosofi og litteratur”, som Habermas påstår; se Habermas, Der philosophische Diskurs der Moderne, 219-47.

8 De to centrale tekster er her "La pharmacie de Platon" (første version publiceret i Tel Quel nr. 32 og 33, 1968), og "La mythologie blanche", in: Derrida, Marges de la philosophie (Paris: Minuit, 1972).

9 Nietzsche I (Pfulingen: Neske: 1961), 95. Man kan notere, at Heidegger overhovedet ikke tildeler æstetikbegrebets historie nogen opmærksomhed, og hvordan det tager form i 1700-tallet i udviklingen fra Baumgarten til Kant. I sin korte historiske skitse i Nietzsche I går han direkte fra Descartes til Hegel, hvilket synes at implicere, at denne historie ikke er andet end en indre fluktuation inden for den cartesianske subjektfilosofiske tradition, hvilket er en klart utilbørlig forenkling.

Io "I alla dessa avseenden är och förblir konsten med avseende på sin högsta bestämning för os något förgånget. Därmed har den för oss också förlorat den äkta sanningen och livfullheten, och är mer förlagd till vår föreställning än den i verkligheten hävdar sin tidigare nödvändighet och intar sin högre plats. Vad som nu uppväcks i oss av konstverk är förutom den omedelbara njutningen också vårt omdöme, i det att vi underkastar innehållet, konstverkets framställningsmedel och bådas lämplighet eller olämplighet vårt tänkande betraktande. I vår tid behöver vi därfor mycket mer en vetenskap om konsten än under de tider då konsten för sig, som konst, redan gav full tillfredsställelse. Konsten inbjuder oss till tänkande betraktande, inte i syfte att åter frammana konst, utan för att få vetenskaplig kunskab om vad konst är." Hegel, Inledning till estetiken (Göteborg: Daidalos, 2005), 16f. For en oversigt over debatten om denne tese, se mit efterskrift, 122-123.

II Heidegger, Platons Lehre von der Wahrheit. Mit einem Brief über den 'Humanismus' (Bern: Francke Verlag, 1954 [2]), 37.

I2 Heidegger, "Der Ursprung des Kunstwerkes", in: Holzwege, Frankfurt a. M.: Vittorio Klostermann, 1994, 1-74: 66n.

I3 “Jeg skylder Dem sandheden i maleriet, og jeg skal fortælle Dem den" (“Jeg vous dois la vérité en peinture, et je vous la dirai”). Brev til Emile Bernard, 23. oktober 1905. I Derridas læsning af denne passage drejer det sig om et løfte og et løfte om sandheden som noget, man er skyldig det vil sige en skyld, som ikke kan gengældes, et løfte som er et paradoks (hvis gaven skal være 
det, den lover, kan den kun bestå i at give det væk, som man ikke har) og en performativ handling; se Derrida, La vérité en peinture, $6 \mathrm{ff}$. Bortset fra Derridas specifikke analyse af de performative paradokser i løftet og gaven, som jo ikke er specifikke for Cézanne - selv om de her skærper problemet vedrørende relationen mellem det tekstuelle og det visuelle: maleren Cézanne lover Bernard at sige ham sandheden "i maleriet" eller "i maleri" (en peinture), men det eneste, som kunne vise denne sandhed, ville være et maleri og ikke længere et udsagn - er det også sandt, at en vis type modernistisk maleriteori, fra den mest sofistikerede til den mest naive, længe har kunnet ernære sig af et mere eller mindre uudtalt fænomenologisk præmis, nemlig at maleriet kan fungere som et paradigme for forsøget på at udtrykke eller vende tilbage til en oprindelig sanselighed, som unddrager sig den tekniske verdens mellemkomst, og at maleriet dermed redder og bevarer noget, som går tabt i de andre medier. Det mest kendte eksempel er her MerleauPontys meditationer over Cézannes sandhed, som udloves og tilbageholdes i kunstnerens stadige forsøg på at artikulere et "første ord"; se Maurice Merleau-Ponty, Cézannes tvivl (København: Edt. Bløndal, 1994). I den følgende udvikling af efterkrigstidens abstrakte maleri tjente fænomenologien som en pålidelig følgesvend, som man kan se i eksempelvis Henry Maldineys essays fra de tidlige 50'ere og fremad, samlede i Regard Parole Espace (Lausanne: L'age d'Homme, 1973), eller, for at tage et samtidigt eksempel, Eliane Escoubas, L'espace pictural (La Versanne: Encre Marine, 1995). Robert Klein giver en kortfattet og temmelig skeptisk oversigt over fænomenologiens kobling til det informelle maleri i 40'erne og 50'erne i “Peinture moderne et phénoménologie", i Klein, La forme et l'intelligible (Paris: Gallimard, 1970). Det ville imidlertid være forhastet udelukkende at koble Cézanne til et fænomenologisk paradigme; se f.eks. Jean-François Lyotard, "Freud enligt Cézanne", Kris 43-44 (1991), som stiller betydningens destrukturering og de sidste maleriers stumhed og uigennemsigtighed, læst i termer af den sønderbrydende "figurale" operation i den libidinale økonomi, over for såvel det teatrale og repræsentationsbaserede rum i psykoanalysen som over for, hvad Lyotard ironisk kalder "fænomenologens godtroenhed".

I4 Kritik af dømmekraften (Frederiksberg: Det lille forlag, 2005), Indledning, afsnit II. Herefter citeret i teksten ved paragrafangivelse.

I5 Jeg låner idéen om "suverænitet" fra Christoph Menke, Die Souveränität der Kunst. Ästhetische Erfahrung nach Adorno und Derrida (Frankfurt am Main: Suhrkamp, 1991). For en lignende diskussion af denne ambivalens hos Kant, se også Jay Bernstein, The Fate of Art, hvor Derrida imidlertid behandles på relativt misvisende vis. Bernstein diskuterer hovedsageligt Derridas læsning af det sublime, mens afsnittene om det skønne, som udgør hoveddelen i "Parergon", i princippet forbigås, på trods af at Bernsteins egen læsning af Kant i mange henseender ligger tæt på Derridas.

I6 Se Von einem neuerdings erhobenen vornehmen Ton in der Philosophie (1796), og Derridas kommentar i D'un ton apocalyptique adopté naguère en philosophie (Paris: Galilée, 1983).

I7 Se Jean-Luc Nancys diskussion i Les muses (Paris: Galilée, 1984), 21 ff. Hele denne udvikling af et ontologisk kunstbegreb analyseres i detaljer med udgangspunkt i Schellings System des transzendentalen Idealismus i Dieter Jähnig, Die Kunst in der Philosophie, 2 vol. (Pfullingen: Neske, 1966-69).

I8 Heidegger opfatter "den frie gunst", et andet af Kants udtryk for interesseløshed, i termer af sit eget begreb "lade-være" (Seinlassen) og forstår det som "den højeste anstrengelse for vort væsen, frisættelsen af vort selv til det, som i sig selv har en værdighed, hvis dette skal kunne ske helt enkelt, skal det ske på en ren måde" (Nietzsche I, 129). Interesseløshedens renhed, fortsætter Heidegger, afskærer os ingenlunde fra relationen til genstanden: "Den væsensmæssige relation 
til formålet selv bliver netop bragt i spil via dette interessefrie" (130).

I9 Denne besynderlige turnering er et eksempel på, hvordan invaginering af inderside og yderside sker, en foldende operation som muliggør den tekstuelle organisation med dens strenge tematiske indhold. I en henseende går fodnoten forud for teksten, dens selvvalgte marginalisering understreger, skriver under, den fordring, som gøres ovenfor, samtidig med at den muliggør en anden læserækkefølge, en anden espacement de la lecture, med Mallarmés ord, som ikke kan sætte sin lid til en enkel modsætning mellem et tematisk centrum og en diffus omgivelse af digressioner og randbemærkninger; se f.eks. Derridas kommentar om læsningens rækkefølge og muligheden for at betragte Kants egen tekst som et værk ( $P$, 57f.). For en mere overordnet diskussion af fodnoten som æstetisk og filosofisk strategi, se Sven-Olov Wallenstein, "The footnote Condition", in: Footnotes on Geopolitics, Market, and Amnesia. 2. Moscow Biennale of Contemporary Art, katalog 2007.

20 For en analyse af dette tema, se Walter Schulz, Metapfysik des Schwebens. Untersuchungen zur Geschichte der Ästhetik (Pfullingen: Neske, 1985). Den tyske romantiks læsning vil her se vejen til en filosofi om det absolutte subjekt; i Heideggers læsning handler det om en radikalisering af endeligheden: "Den følgende fortolkning," siger Heidegger i Kant und das Problem der Metaphysik, "er vokset frem af en anden problemstilling og bevæger sig så at sige i modsat retning i forhold til den tyske idealisme" (§ 27, note). Derrida følger i denne henseende Heidegger et stykke af vejen, men understreger, at den "fælles rod" for anskuelse og tænkning, som Heidegger vil finde hos Kant, aldrig kan gribes i andet end sin deling.

2I For en diskussion af dette problem, se Bernstein, The Fate of Art, 21ff., og Paul Guyer, Kant and the Claims of Taste (Cambridge, Mass.: Harvard University Press, 1979), kap. 8.

22 Kant indfører et hierarki af formål, hvor den afgørende distinktion er den mellem sidste formål (letzte Zweck) og slutgyldigt formål (Endzweck). Naturen kan forstås som et hierarki af væsner, hvor de lavere tjener de højere, og i denne rangordning kan mennesket forstås som et sidste formål i den forstand, at det i egenskab af et sanseligt eksisterende væsen stræber efter en højeste lyksalighed, som imidlertid altid forbliver sanseligt betinget. På et principielt andet niveau gælder mennesket dog som et moralsk væsen, og der kan det siges at udgøre et ubetinget og slutgyldigt formål, og bare som sådant kan mennesket give hele eksistensen en mening. Det er på dette niveau, at det i praktisk-moralsk, men ikke i teoretisk-spekulativ henseende bliver meningsfuldt at tale om en ophavsmand til verden, en Gud som har skabt den, for at den skal kunne befordre, eller i det mindste ikke modvirke, menneskets evne til at sætte sig selv som højeste formål. Når Kant i § 42 taler om den "chifferskrift, som naturen i sine smukke former figurligt taler til os gennem," er dette chiffers betydning i sidste instans den, at vi må kunne tænke os verden som indrettet for vores moralske behovs skyld, at der altså må findes en i det mindste mulig harmoni mellem teoretisk og praktisk fornuft, selv om denne kun bliver tilgængelig for os via et chiffer eller et "vink om, at [naturen] i sig indeholder en grund til at antage en lovmæssig overensstemmelse mellem dens frembringelser og vort af enhver interesse uafhængige velbehag." 